\title{
Investment Climate in Bangladesh: Performance and Possibilities
}

\section{Joynal Abdin*}

Program Officer, Planning, Monitoring and Evaluation Wing of SME Foundation, Dhaka, Bangladesh

\begin{abstract}
Bangladesh achieved lower-middle income country's status from the World Bank in July 2015. It's GNI per capita raised into USD 1314 in 2014-15 FY from USD 1184 and USD 1054 in 2012-13 and 2013-14 Fiscal Years respectively. The government of Bangladesh declared Vision 2021 to be a higher middle income country by the year 2021. Therefor it has only 6 years in hand to raise GNI per capita from existing USD 1314 into USD 4126 to become a higher middle income country. There are many other challenges in front of it like; about $31.5 \%$ population is living below poverty line, there are 56.7 million workable populations in Bangladesh with 2 million unemployed populations. About 1.8 million educated workforces are entering into the job market in each year. GDP Growth rate is rotating around $6 \%$ to $6.6 \%$ during last decades, but it has to be increased into $8 \%$ to $10 \%$ to facilitate employment generation and poverty alleviation in Bangladesh. A huge amount of new investment is required to increase GDP growth and employment rate up to the desired level. There are options to increase local investment as well as go for foreign direct investment but preparations shall be taken in time. Otherwise Vision 2021 may not be achieved even by the year 2031. This is the time to compare Bangladesh's performance in local and foreign investment attraction with its competitor countries. Current investment attraction tools using by the government of Bangladesh could be rechecked and initiate effective corrective measures as, when and where required.
\end{abstract}

Keywords: Investment climate in Bangladesh; Investment scenario in Bangladesh; Trend of local investment in Bangladesh; Trend of fdi into Bangladesh; Economic growth through investment promotion; Employment generation and poverty alleviation through investment promotion

JEL Code: D92, E22, F21, P33, R42

\section{Introduction}

Bangladesh is one of the promising Least Developed Countries (LDCs) having potentials to grow further. Goldman Sachs investment bank described Bangladesh as one of the Next-11 countries (N-11) due to its prompt growth potentials [1].

The economy of Bangladesh is growing with an on an average 6-7\% growth rate during last decade. Present government aimed to reach into the status of middle income country by 2021 and graduate from the list of LDC. To transform Bangladesh into a middle income country we must have to attain few targets like; achieve and sustained annual rate of GDP at 10 per cent by 2021 , substantially eradicate poverty by bringing down the number of people living below the poverty line to 15 percent of the population estimated at no more than 25 million, change the sectorial composition of output with the shares of agriculture, industry, and services approximating 15 percent, 38 percent, and 47 percent respectively by 2021 .

We have to reduce the unemployment rate to 15 per cent; change the shares of agriculture, industry, and services in employment to 30 per cent, 25 per cent, and 45 per cent respectively by 2021 . To achieve this change in the economy Bangladesh has to generate 11,500 MW electricity by 2015 , and make provisions to meet the expected demand for power of 20,000 MW by 2021 [2].

On the other hand about $31.5 \%$ of Bangladeshis are living below the poverty line [3]. There are 56.7 million workable populations in Bangladesh with 2 million unemployed populations [4]. Another 1.8 million educated workforce is entering into the job market per year [5]. Providing employment opportunity to such a huge population is quite difficult task for the government as well as for the local private sector. Therefore government has to go for foreign investment into Bangladesh to facilitate employment opportunity, foster economic growth and poverty alleviation.
To achieve all of the above mentioned targets by 2021 Bangladesh has only one option i.e. increasing investment. GDP growth rate was $6.06 \%$ in 2013-14 FY [6,7] but it was supposed to be increased into $8 \%$ by 2013 furthermore $10 \%$ by 2017 as per vision 2021 [8].

By investing 28.58\% of GDP Bangladesh achieved 6.06\% growth rate in $2013-14 \mathrm{FY}$ it has to be increased into $34.4 \%$ to get $8 \%$ GDP growth. That means we have to invest about $5.82 \%$ of our total GDP (Total GDP is BDT $13,509,204$ million, BBS 2014) i.e. BDT 786.23 billion or USD 9.82 billion more to get targeted 8\% GDP growth of Bangladesh economy.

Investing such a huge amount may not be possible from internal sources only. We must have to go for foreign investment to achieve vision 2021 in time, increase GDP growth rate into $8 \%$ in near future, and be a middle income country by the year 2021 .

\section{Problem statement and research question}

Bangladesh has to be higher middle income country within the year 2021. But a significant amount of its population is living below poverty line with a major unemployment figure. Number of educated job seekers is increasing day by day. There is a little effort to divert these jobseekers into entrepreneurship development or self-employment creation process by the government. Local and foreign investment has to be raised to increase GDP growth into double digit. The Board of Investment is organizing international road shows to attract foreign investment but its response is not satisfactory level till now. How the competitor countries like Vietnam are attracting foreign investment? What types of new initiative could be taken to increase local and foreign investment in Bangladesh?

${ }^{*}$ Corresponding author: Md. Joynal Abdin, Program Officer, Planning, Monitoring and Evaluation Wing of SME Foundation, Dhaka, Bangladesh, Tel: +88-028142983; E-mail: mdjoynal@gmail.com

Received August 20, 2015; Accepted September 01, 2015; Published September 06, 2015

Citation: Abdin J (2015) Investment Climate in Bangladesh: Performance and Possibilities. Int J Econ Manag Sci 4: 290. doi:10.4172/21626359.1000290

Copyright: @ 2015 Abdin J. This is an open-access article distributed under the terms of the Creative Commons Attribution License, which permits unrestricted use, distribution, and reproduction in any medium, provided the original author and source are credited. 


\section{Objective of this study}

Main objective of this study is to know about the investment attraction packages offering by Bangladesh for the local and foreign investors. How much local and foreign investment Bangladesh has received during last ten years? How its competitor countries are doing in terms of local and foreign investment attractions? We would like to know about the challenges and recommend ways forward to increase investment into Bangladesh.

\section{Methodology}

To conduct this study the researcher would like to go through investment relevant law, acts, incentive packages offered by the government of Bangladesh and other relevant agencies. We would like to know investment trend into Bangladesh during last ten years. Identifying the sectors received maximum foreign investment in last ten years. We would like to compare FDI attraction performance of few selected South and Southeast Asian countries along with the origin of investment. We would like to depends upon a popular market analysis tools namely ITC Investment Map to get international data. At the same time government published data and referred journals could get priority in terms of acceptability of data and information to be used in this study.

\section{Scope of the work}

Analyzing current performance of the selected countries in attracting foreign investment based on available secondary data sources like ITC investment map. Government published data (in case of availability) shall get priority to reflect the actual scenario. International standard of citation will be strictly followed by the author to maintain high professionalism and acceptability of the study. Looking after the challenges and recommending ways forward could be a major part of this study.

\section{Limitation of this study}

The whole study is conducted based on secondary literature, data and information. This is one of the major limitations of this study. This study could be more effective if adequate number of stakeholders could be interviewed from each country and incorporate their experience driven opinions in it. A broad based primary study could give it a new dimension in terms of efficiency and effectiveness of the recommendations.

\section{Literature review}

Bangladesh is a rapidly growing economy in South Asia. It is a market of 160 million populations and their purchasing power is rising day by day. It is offering 56.7 million workable populations with most competitive salaries and wages (LFS) [4]. All the factors of production are cheaper in Bangladesh than that of the other South and Southeast Asian countries. Bangladesh enjoys tariff free market access to the European, Canadian, Australian and Japanizes markets. According to the World Bank's Doing Business Index [9] Bangladesh's position are 107 among 183 countries which is well above than the countries like
India or Indonesia. Renowned investment banker Goldman Sachs's indicated Bangladesh as one of the next eleven countries (N11) having potentials to be one of the largest economy of the world. Bangladesh was listed in 2007as one of five countries with impressive economic and investment potential (JP Morgan's Frontier Five). Bangladesh received its credit ratings (BB- and $\mathrm{Ba} 3$ ) in 2010. Moody's rating puts Bangladesh on par with Vietnam (Kingdom of the Netherlands [10].

The Government of Bangladesh has taken a number of steps to create a facilitating environment for the private sector so that it plays its due role as an effective economic agent and makes substantial contribution to the overall economic development of the country. As a result, total investment increased from BDT 1261 billion in 2005-06 FY to BDT 4384 billion in 2014-15 FY [6,7].

Bangladesh changed its socialist mentality and successfully adopted global free market economy in late 90s. A series of policy incentives, investment sovereignty has been offered to the FDI investors including tax holiday for several years, duty free facility for importing capital machinery, $100 \%$ foreign ownership, $100 \%$ profit repatriation facility, reinvestment of profit or dividend as FDI, multiple visa, work permit to foreign executives, permanent resident or even citizenship for investing a specific amount, Export Processing Zone (EPZ) facility, and easy hassle free exit facility. As a result it got FDI investment got momentum from USD 0.09 million in 1972 into USD 356 million in 1995 [11].

Major industrial sectors of Bangladesh includes textiles, readymade garment, telecommunication, ICT, energy and gas, infrastructure development, leather goods, plastic goods, jut goods, light engineering, ceramics, agro-processing, and ship building etc. Muttakin and Ahmed $[12,13]$ identified complex bureaucracy, weak infrastructure, political unrest, and absence of good governance, lack of entrepreneurship development initiative, absence of effective judiciary, poor capital market, and lack of adequate information, complex approval procedures and poor industrial base as major barrier to attract FDI into Bangladesh.

\section{Current Trend of Investment in Bangladesh}

\section{Local investment}

From the statistics of last ten years (2005-06 Base year) it is quite clear that, private sector is leading the trend of investment in Bangladesh (Table 1).

Investment in Bangladesh is rising very slowly. Therefore it failed to achieve projected growth rate as per vision 2021. It was supposed to achieve 8\% GDP growth in 2013 but in 2015 we observed that GDP growth rate is still below $6.5 \%$. Therefore we have no alternative but to increase investment in Bangladesh.

\section{FDI inflows in Bangladesh}

From the following Table 2 it is quite clear that the trend of FDI inflow in Bangladesh experienced several fluctuations during last ten years. Foreign investment into Bangladesh was remaining UDS 800

\begin{tabular}{|c|c|c|c|c|c|c|c|c|c|c|}
\hline Fiscal Year & 2005-06 & 2006-07 & 2007-08 & 2008-09 & $2009-10$ & $2010-11$ & 2011-12 & 2012-13 & 2013-14 & 2014-15 \\
\hline Total Investment & 1261 & 1439.3 & 1647.3 & 1847.7 & 2093.3 & 2511.3 & 2982.3 & 3403.7 & 3839.9 & 4384.4 \\
\hline Public Investment & 268.3 & 280.2 & 282.8 & 304.4 & 372.8 & 481.5 & 608 & 796.2 & 879.9 & 1044.2 \\
\hline Private Investment & 992.7 & 1159.2 & 1364.5 & 1543.3 & 1720.5 & 2029.8 & 2374.2 & 2607.5 & 2960 & 3340.2 \\
\hline
\end{tabular}

Source: Bangladesh Economic Review [6]. 


\begin{tabular}{|c|c|c|c|c|c|c|c|c|c|c|}
\hline Fiscal Years & 2004-05 & 2005-06 & 2006-07 & 2007-08 & 2008-09 & $2009-10$ & 2010-11 & 2011-12 & 2012-13 & 2013-14 \\
\hline Foreign Direct Investment (Net) & 800 & 675 & 793 & 748 & 961 & 818 & 775 & 1191 & 1726 & 1550 \\
\hline \multicolumn{11}{|l|}{$\begin{array}{l}\text { Source: Compiled by the author from- } \\
\text { 1. Bangladesh Economic Review [7] } \\
\text { 2. Bangladesh Economic Review [15]. }\end{array}$} \\
\hline
\end{tabular}

Table 2: FDI Inflows in Bangladesh USD in million.

\begin{tabular}{|c|c|c|c|c|c|c|c|c|c|c|}
\hline Components/FY & 2004-05 & 2005-06 & 2006-07 & 2007-08 & 2008-09 & 2009-10 & 20010-11 & 2011-12 & $2012-13$ & 2013-14 \\
\hline Equity Capital & 361.14 & 447.22 & 464.5 & 545.69 & 535.42 & 515.14 & 249.95 & 454.1 & 761.03 & 270.59 \\
\hline Reinvested earnings & 297.11 & 198.64 & 281 & 197.71 & 336.61 & 331.1 & 445.19 & 542.35 & 645.64 & 795.81 \\
\hline Intercompany loans & 145.53 & 89.75 & 47.24 & 25.29 & 88.56 & 66.78 & 83.9 & 198.43 & 323.96 & 429.1 \\
\hline Total FDI Inflows & 803.78 & 744.61 & 792.74 & 768.69 & 960.59 & 913.02 & 779.04 & 1194.88 & 1730.63 & 1495.5 \\
\hline
\end{tabular}

Source: Foreign Direct Investment [22].

Table 3: Component wise distribution of FDI Inflows USD in million.

\begin{tabular}{|c|c|c|c|c|c|c|c|c|c|c|}
\hline Fiscal Years & 2005-06 & 2006-07 & 2007-08 & 2008-09 & $2009-10$ & $2010-11$ & 2011-12 & 2012-13 & 2013-14 & 2014-15 \\
\hline Percentage of GDP Invested (\%) & 26.1 & 26.2 & 26.2 & 26.2 & 26.2 & 27.4 & 28.3 & 28.4 & 28.6 & 29 \\
\hline GDP Growth Rate (\%) & 6.67 & 7.06 & 6.01 & 5.05 & 5.57 & 6.46 & 6.52 & 6.01 & 6.06 & 6.51 \\
\hline
\end{tabular}

Source: Bangladesh Economic Review [7].

Table 4: Investment vs. GDP Growth (\% of GDP)

million to USD 900 million till 2010. After that while a major amount of investment came into telecom sector the figure crossed USD 1 thousand million $[14,15]$.

\section{Component wise distribution of FDI inflows during last 10 years}

If we would like to analyze FDI inflows according to the components then one fact be clear to us that, total FDI inflows amount is increasing but fresh FDI is not coming into Bangladesh accordingly. Maximum contribution of the total amount's hick comes from Reinvestment of locally earnings. Fresh FDI as Equity capital is not rising rather decreasing in recent years (Table 3).

Reinvestment of locally earned profit could increase the FDI figure academically. But practically it is not adding value in terms of increasing foreign currency, new employment or bringing new technology into Bangladesh. Therefore we are in need of attracting fresh investment into Bangladesh. Promoting new sectors and exploring new sources for FDI attraction.

\section{Investment vs. GDP growth (\% of GDP)}

From the following Table 4 it is quite clear that, there is a positive correlation between percentage of GDP invested and GDP growth rate.

From 2005-06 to till date investment is below 30\% of GDP in Bangladesh therefor GDP growth rate is also below 7\%. We have to increase investment up to $32 \%$ to achieve $7 \%$ GDP growth. Similarly investment has to be increased up to 34.5 or more in percentage of GDP to achieve $8 \%$ growth $[16,17]$.

\section{Current Trend of FDI Inflow in Some Selected South and Southeast Asian countries}

We can observe from the following table that, countries ensures good governance, transparency and better law and order situation enjoyed more FDI than that of the others. Singapore, Malaysia, Thailand and India are the samples of attracting FDI through good governance and stable political environment.
Countries governing by the autocratic leaders like Cambodia do not get FDI. Iran is doing comparatively better in attracting FDI even in a sanction condition. Pakistan and Bangladesh are experiencing fluctuations due to the political unrest and corrupt bureaucracy. Vietnam is getting much more FDI than Bangladesh even after a civil war against the strongest superpower of the world. Vietnam has strong political commitment, secure regulatory regime and better drive to attract new investment into it $[18,19]$.

Vietnam has almost same size of GDP but it attracted USD 23107.3 million, 19886.1 million, and 15598.1 million in 2009, 2010, and 2011 whereas Bangladesh got USD 700.2 million, 913.3 million and 1136.4 million respectively. This shows a clear distinction of performance of Vietnam and Bangladesh [20].

In the above Table 5 and Figure 1 we can observe that 2007 was a black year for attracting FDI into South and Southeast Asian countries. This could be happened due to the Asian Financial Crisis in the same year. It happened again in 2009 and 2010 due to the Global Financial Crisis in 2008-09 FY. Without some expectations all the countries get back their upward momentum in 2011.

\section{FDI inflow (net) in\% of GDP}

From the following Figure 2 we can see that, Singapore is the regional leader in attracting maximum FDI about $27 \%$ of its GDP. Similarly Singapore experienced maximum fluctuations due to repatriation of earning by the FDI investors. Malaysia, Vietnam and Thailand is also getting comparatively more FDI i.e. about $7-8 \%$ of respective GDPs.

\section{Top ten sectors of the selected countries attracting more FDI}

From the Table 6, we observed that, textile, clothing and leather sector is dominating for getting FDI into the selected countries. Bangladesh, Cambodia and Iran got maximum FDI in this sector readymade garment and textile sector of Bangladesh got South Korean, Sri Lankan and Indian FDI. Similarly Cambodia and Iran is also got maximum FDI in these sectors. Finance is the second largest sector to attract FDI into these states, namely Bangladesh, Cambodia, Iran, 


\begin{tabular}{|c|c|c|c|c|c|c|c|c|c|c|c|}
\hline Y/C & $\begin{array}{c}\text { GDP in USD } \\
\text { billion }\end{array}$ & 2003 & 2004 & 2005 & 2006 & 2007 & 2008 & 2009 & 2010 & 2011 & 2012 \\
\hline Bangladesh & 185.41 & 350.2 & 460.4 & 845.3 & 792.5 & 666.4 & 1086.3 & 700.2 & 913.3 & 1136.4 & 1191 \\
\hline Cambodia & 16.55 & 84 & 131.4 & 381.3 & 483.2 & 867.3 & 815.2 & 539.1 & 782.6 & 891.8 & 387 \\
\hline India & 2049.5 & 1462 & 2320 & 3359 & 9307 & 19425 & 22697 & 22461 & 14939 & 23473 & 18286 \\
\hline Iran & 404.13 & 3037.3 & 2889.2 & 2317.5 & 2017.8 & 1980 & 2983.4 & 3649 & 4276.7 & 4661.7 & 3049.9 \\
\hline Malaysia & 326.93 & 2473.2 & 4624.2 & 3964.8 & 6059.7 & 8401.2 & 7178.5 & 1453.1 & 9058.9 & 12201.2 & 10074.3 \\
\hline Pakistan & 250.13 & 531.8 & 1117.3 & 2200.3 & 4272.4 & 5591.3 & 5436.9 & 2338.4 & 1820.8 & 1326.2 & 1150.3 \\
\hline Singapore & 308.05 & 14819.4 & 20080.5 & 36924 & 47733.3 & 12200.7 & 23821.3 & 55075.8 & 50367.7 & 61159.4 & 63772.3 \\
\hline Si Lanka & 74.58 & 233 & 272 & 480 & 603.4 & 752.2 & 404 & 477.6 & 981.1 & 941.1 & 915.6 \\
\hline Thailand & 373.8 & 3411 & 5165 & 4956 & 8048.1 & 9459.6 & 11331.3 & 8547.1 & 4853.5 & 9689.8 & 9539 \\
\hline Vietnam & 186.04 & 1450.1 & 1610.1 & 2020.8 & 12003.8 & 6981 & 64011 & 23107.3 & 19886.1 & 15598.1 & 16348 \\
\hline
\end{tabular}

Source: Compiled by the Author from the following sources:

a. The International Monetary Fund [24].

b. ITC Investment Map [23].

Table 5: Current Trend of FDI Inflow in some selected countries USD in million.

Current Trend of FDI Inflow in Some Selected South and Southeast Asian Countries

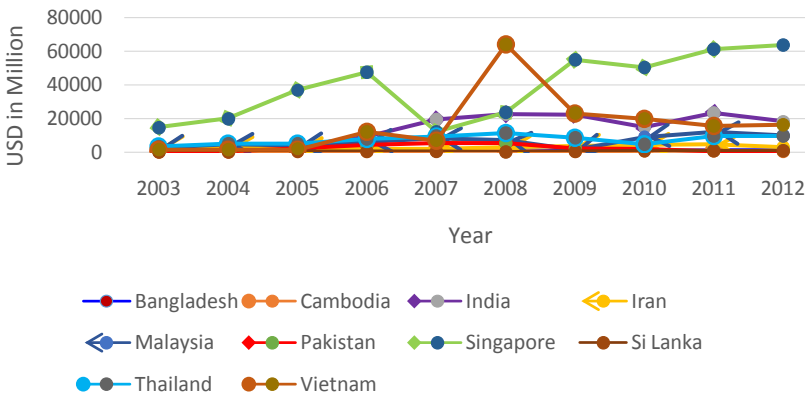

Figure 1: Current Trend of FDI Inflow in Some Selected Countries.

Pakistan, Malaysia, and Thailand got second largest amount of FDI in this sector. Transport, Storage and Communication is the $3^{\text {rd }}$ largest FDI receiving sector in the selected countries $[21,22]$.

\section{Major sources of investment into the selected countries}

Netherlands has FDI into most of the selected countries of South and Southeast Asia. It is one of the major investors in Bangladesh, India, Malaysia, Sri Lanka, and Thailand. The USA and UK are also investing into these countries. USA and UK has FDI investment in Bangladesh, India, Pakistan etc. states. One notable fact is observed here that, the regional leader of FDI attraction i.e. Singapore do not have much FDI from the western countries like USA or UK or Netherlands. Rather maximum Investment goes to Singapore from Brunei, China, Hong Kong, India, Indonesia, Israel, Japan, Korea and Laos. Vietnam is the only country having FDI from both western and regional states like Japan, Singapore, South Korea, Taiwan, British Virgin Island, Hong Kong, USA, Malaysia, China and Thailand [23-26] (Table 7).

Another notable fact is that, maximum FDI into the Singapore and Vietnam comes from their neighboring countries not from the Europe or America. Therefore Bangladesh could learn the fact that, neighboring countries could be major source of FDI if we have congenial relationship with India, China, Hong Kong, Taiwan, Japan and Brunei etc. countries. Therefor our investment promotion missions shall go to Hong Kong, Taiwan, Brunei etc. states rather than to the western world $[27,28]$.

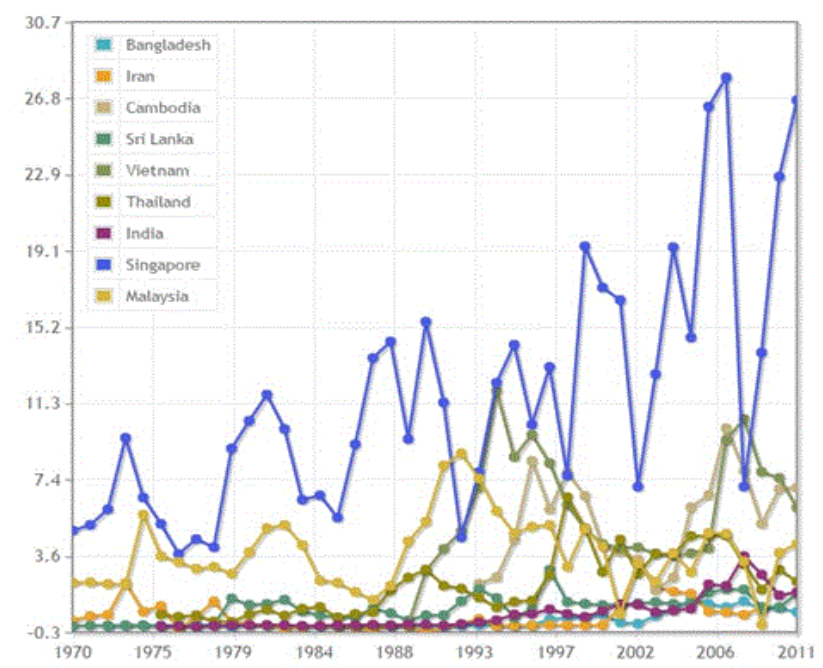

Source: World Bank [17].

Figure 2: FDI in percentage of GDP of the selected countries.

\section{Determinants of FDI: Bangladesh Perspectives}

There are many theories and research finding regarding the factor affecting FDI decision of an investor. Few major determinants are as follows:

1. Size of local market: Bangladesh is a steadily growing market of about 160 million people. Purchasing power of local consumers is rising day by day. It is located at a strategic position to reach into half of the world's population market existing in India and China easily. Therefor it has a potential to be regional hub of the channel of distribution in near future.

2. Regulatory environment: The government of Bangladesh offered a long list of fiscal and non-fiscal incentives to attract FDI.

\section{Facilities and incentives for a foreign investor}

i. Remittances of up to $50 \%$ of salaries of the foreigners employed in Bangladesh and facilities for repatriation of their savings and retirement benefits at the time of their return. 


\begin{tabular}{|c|c|c|c|c|c|c|c|c|c|}
\hline Bangladesh & Cambodia & India & Iran & Malaysia & Pakistan & Singapore & Sri Lanka & Thailand & Vietnam \\
\hline $\begin{array}{l}\text { Textiles, clothing } \\
\text { and leather }\end{array}$ & $\begin{array}{l}\text { Textiles, clothing } \\
\text { and leather }\end{array}$ & $\begin{array}{l}\text { Unspecified } \\
\text { secondary }\end{array}$ & $\begin{array}{l}\text { Textiles, clothing } \\
\text { and leather }\end{array}$ & $\begin{array}{l}\text { Unspecified } \\
\text { secondary }\end{array}$ & Petroleum & $\begin{array}{l}\text { Agriculture } \\
\text { and hunting }\end{array}$ & $\begin{array}{l}\text { Chemicals } \\
\text { and chemical } \\
\text { products }\end{array}$ & $\begin{array}{l}\text { Machinery and } \\
\text { equipment }\end{array}$ & $\begin{array}{l}\text { Unspecified } \\
\text { secondary }\end{array}$ \\
\hline Finance & $\begin{array}{l}\text { Agriculture and } \\
\text { hunting }\end{array}$ & $\begin{array}{l}\text { Hotels and } \\
\text { restaurants }\end{array}$ & Finance & $\begin{array}{l}\text { Mining and } \\
\text { quarrying }\end{array}$ & Finance & $\begin{array}{l}\text { Business } \\
\text { activities }\end{array}$ & $\begin{array}{c}\text { Food, } \\
\text { beverages and } \\
\text { tobacco }\end{array}$ & Finance & $\begin{array}{l}\text { Business } \\
\text { activities }\end{array}$ \\
\hline $\begin{array}{l}\text { Electricity, gas } \\
\text { and water }\end{array}$ & Finance & Finance & $\begin{array}{l}\text { Electricity, gas } \\
\text { and water }\end{array}$ & Finance & $\begin{array}{l}\text { Chemicals } \\
\text { and chemical } \\
\text { products }\end{array}$ & $\begin{array}{l}\text { Chemicals } \\
\text { and chemical } \\
\text { products }\end{array}$ & $\begin{array}{l}\text { Metal and metal } \\
\text { products }\end{array}$ & $\begin{array}{l}\text { Unspecified } \\
\text { secondary }\end{array}$ & $\begin{array}{l}\text { Wholesale and } \\
\text { retail trade }\end{array}$ \\
\hline $\begin{array}{l}\text { Transport, } \\
\text { storage and } \\
\text { communications }\end{array}$ & $\begin{array}{l}\text { Hotels and } \\
\text { restaurants }\end{array}$ & $\begin{array}{l}\text { Electricity, gas } \\
\text { and water }\end{array}$ & $\begin{array}{c}\text { Transport, } \\
\text { storage and } \\
\text { communications }\end{array}$ & $\begin{array}{l}\text { Wholesale and } \\
\text { retail trade }\end{array}$ & $\begin{array}{l}\text { Motor vehicles } \\
\text { and other } \\
\text { transport } \\
\text { equipment }\end{array}$ & $\begin{array}{c}\text { Coke, } \\
\text { petroleum } \\
\text { products and } \\
\text { nuclear fuel }\end{array}$ & $\begin{array}{c}\text { Non-metallic } \\
\text { mineral products }\end{array}$ & $\begin{array}{l}\text { Electrical and } \\
\text { electronic } \\
\text { equipment }\end{array}$ & $\begin{array}{l}\text { Transport, } \\
\text { storage and } \\
\text { communications }\end{array}$ \\
\hline $\begin{array}{c}\text { Non-metallic } \\
\text { mineral products }\end{array}$ & $\begin{array}{l}\text { Business } \\
\text { activities }\end{array}$ & Construction & $\begin{array}{c}\text { Non-metallic } \\
\text { mineral products }\end{array}$ & $\begin{array}{c}\text { Unspecified } \\
\text { tertiary }\end{array}$ & $\begin{array}{l}\text { Electricity, gas } \\
\text { and water }\end{array}$ & Construction & $\begin{array}{c}\text { Other } \\
\text { manufacturing }\end{array}$ & $\begin{array}{l}\text { Business } \\
\text { activities }\end{array}$ & Construction \\
\hline $\begin{array}{l}\text { Chemicals } \\
\text { and chemical } \\
\text { products }\end{array}$ & $\begin{array}{c}\text { Transport, } \\
\text { storage and } \\
\text { communications }\end{array}$ & $\begin{array}{l}\text { Business } \\
\text { activities }\end{array}$ & $\begin{array}{l}\text { Chemicals } \\
\text { and chemical } \\
\text { products }\end{array}$ & $\begin{array}{c}\text { Transport, } \\
\text { storage and } \\
\text { communications }\end{array}$ & Construction & $\begin{array}{l}\text { Electrical } \\
\text { and } \\
\text { electronic } \\
\text { equipment }\end{array}$ & $\begin{array}{l}\text { Textiles, clothing } \\
\text { and leather }\end{array}$ & $\begin{array}{l}\text { Chemicals } \\
\text { and chemical } \\
\text { products }\end{array}$ & $\begin{array}{l}\text { Mining and } \\
\text { quarrying }\end{array}$ \\
\hline $\begin{array}{c}\text { Other } \\
\text { manufacturing }\end{array}$ & $\begin{array}{l}\text { Food, beverages } \\
\text { and tobacco }\end{array}$ & $\begin{array}{l}\text { Unspecified } \\
\text { tertiary }\end{array}$ & $\begin{array}{c}\text { Other } \\
\text { manufacturing }\end{array}$ & $\begin{array}{l}\text { Agriculture and } \\
\text { hunting }\end{array}$ & $\begin{array}{c}\text { Non-metallic } \\
\text { mineral products }\end{array}$ & Finance & $\begin{array}{l}\text { Unspecified } \\
\text { tertiary }\end{array}$ & $\begin{array}{c}\text { Rubber and } \\
\text { plastic products }\end{array}$ & $\begin{array}{c}\text { Health and } \\
\text { social services }\end{array}$ \\
\hline $\begin{array}{l}\text { Food, beverages } \\
\text { and tobacco }\end{array}$ & Petroleum & $\begin{array}{l}\text { Wholesale and } \\
\text { retail trade }\end{array}$ & $\begin{array}{l}\text { Food, beverages } \\
\text { and tobacco }\end{array}$ & Construction & $\begin{array}{l}\text { Business } \\
\text { activities }\end{array}$ & $\begin{array}{c}\text { Food, } \\
\text { beverages } \\
\text { and tobacco }\end{array}$ & $\begin{array}{l}\text { Wood and wood } \\
\text { products }\end{array}$ & $\begin{array}{l}\text { Mining and } \\
\text { quarrying }\end{array}$ & $\begin{array}{l}\text { Hotels and } \\
\text { restaurants }\end{array}$ \\
\hline $\begin{array}{l}\text { Unspecified } \\
\text { tertiary }\end{array}$ & $\begin{array}{l}\text { Coke, petroleum } \\
\text { products and } \\
\text { nuclear fuel }\end{array}$ & $\begin{array}{c}\text { Transport, } \\
\text { storage and } \\
\text { communications }\end{array}$ & $\begin{array}{c}\text { Unspecified } \\
\text { tertiary }\end{array}$ & $\begin{array}{l}\text { Business } \\
\text { activities }\end{array}$ & $\begin{array}{l}\text { Coke, petroleum } \\
\text { products and } \\
\text { nuclear fuel }\end{array}$ & $\begin{array}{l}\text { Hotels and } \\
\text { restaurants }\end{array}$ & & $\begin{array}{c}\text { Food, } \\
\text { beverages and } \\
\text { tobacco }\end{array}$ & Education \\
\hline $\begin{array}{l}\text { Metal and metal } \\
\text { products }\end{array}$ & $\begin{array}{l}\text { Community, } \\
\text { social and } \\
\text { personal service } \\
\text { activities }\end{array}$ & Education & $\begin{array}{l}\text { Metal and metal } \\
\text { products }\end{array}$ & Others & $\begin{array}{l}\text { Textiles, clothing } \\
\text { and leather }\end{array}$ & $\begin{array}{l}\text { Machinery } \\
\text { and } \\
\text { equipment }\end{array}$ & & $\begin{array}{l}\text { Transport, } \\
\text { storage and } \\
\text { communications }\end{array}$ & $\begin{array}{l}\text { Agriculture and } \\
\text { hunting }\end{array}$ \\
\hline
\end{tabular}

Source: ITC Investment Map [23]

Table 6: Sector attracting more FDI into the selected countries.

\begin{tabular}{|c|c|c|c|c|c|c|c|c|c|c|}
\hline SI. & Bangladesh & Cambodia & India & Iran & Malaysia & Pakistan & Singapore & Sri Lanka & Thailand & Vietnam \\
\hline $\mathbf{1}$ & $\begin{array}{c}\text { United Arab } \\
\text { Emirates }\end{array}$ & China & Mauritius & Jordan & Japan & USA & Brunei Darussalam & China & Japan & Japan \\
\hline $\mathbf{2}$ & $\begin{array}{c}\text { Kingdom of Saudi } \\
\text { Arabia (KSA) }\end{array}$ & South Korea & Singapore & Lebanon & Singapore & UK & Cambodia & Hong Kong & Hong Kong & Singapore \\
\hline $\mathbf{3}$ & UK & Malaysia & USA & Georgia & Netherlands & UAE & China & Singapore & Netherlands & South Korea \\
\hline $\mathbf{4}$ & USA & Taiwan & UK & Kazakhstan & Honk Kong & Japan & Hong Kong & Netherlands & Malaysia & Taiwan \\
\hline $\mathbf{5}$ & Netherlands & Hong Kong & Netherlands & Bahrain & $\begin{array}{c}\text { British Virgin } \\
\text { Islands }\end{array}$ & Hong Kong & India & Malaysia & Singapore & British Virgin \\
Island
\end{tabular}

Sources: Compiled by the author from the different sources [19-21,25-28,].

Table 7: Sources of FDI into the selected countries.

ii. No restrictions on issuance of work permits to project related foreign nationals and employees.

iii. Facilities for repatriation of invested capital, profits and dividends.

iv. Provision of transfer of shares held by foreign shareholders to local investors.

v. Reinvestment of remittable dividends would be treated as new investment. vi. Level playing field: foreign owned companies duly registered in Bangladesh will be on the same footing as locally owned ones.

\section{Fiscal incentives}

1. Accelerated depreciation on cost of machinery is admissible for new industrial undertaking ( $50 \%$ in the first year of commercial production, $30 \%$ in the second year, and $20 \%$ in the third year).

\section{Financial incentives for export oriented industries}

ii. Cash incentives and export subsidies ranging from $5 \%$ to $20 \%$ 
granted on the FOB value of the selected products.

iii. $90 \%$ loans against letters of credit (by banks).

iv. Permission for domestic market sales of up to $20 \%$ of exportoriented companies outside EPZ (relevant duties apply).

\section{Additional facilities/incentives}

v. $100 \%$ foreign equity allowed.

vi. Unrestricted exit policy.

vii. Remittance of royalty, technical know-how and technical assistance fees.

viii. Full repatriation facilities of dividends and capital at exit.

ix. Citizenship by investing a minimum of US $\$ 5,00,000$.

x. Permanent resident permits on investing US\$ 75,000.

xi. An investor can wind up investment either through a decision of the AGM or EGM. He or she can repatriate the sales proceeds after securing proper authorization from the Central Bank.

3. Labor cost and productivity: According to a recent survey report of JETRO Dhaka is offering more competitive price for all factors of production than that of the other South and Southeast Asian cities. So it shall get more attention for relocating industries into Bangladesh.

4. Political Risk: Bangladesh has only one disadvantage that we have a non-compromising tendency among our political parties. As a result political violence occurs and caused into life and wealth damage. We have to overcome this major barrier to get attention of FDI investors.

5. Infrastructure: We have two Sea Ports, national highways and going to establish Deep Sea Port in near future. We have to develop alternative of Dhaka - Chittagong highway to reduce lead time for exportable products.

6. Economic growth: Bangladesh economy is rising on an average $6-7 \%$ growth during last decade. It is resilience as well as potentials to grow further into double digit if good governance could be ensured.

7. Tax regime of the host country: Bangladesh is offering a long range of tax benefits for FDI investors including;

i. Tax exemption on royalties, technical knowhow and technical assistance fees and facilities for their repatriation.

ii. Tax exemption on interests on foreign loans.

iii. Tax exemptions on capital gains from transfer of shares by the investing company.

iv. Corporate tax holiday of 5 to 7 years for selected sectors.

v. Reduced tariff on import of raw materials capital machinery.

vi. Bonded warehousing.

vii. Tax exemption on capital gains from the transfer of shares of public limited companies listed with a stock exchange.

viii. Reduced Corporate Tax for 5 to 7 years in lieu of tax holding and agricultural depreciation.

\section{Bangladesh's Initiatives to Attract FDI}

Besides all the above mentioned fiscal and non-fiscal incentives Bangladesh undertake a series of initiatives to attract FDI. These are as follows:

\section{Reforms and liberalizations}

i. Bangladesh opened up its market for foreign investment up to $100 \%$ foreign ownership without few reserved sectors like production of arms and ammunition and other defense equipment, and machinery, forest plantation and mechanized extraction within the bounds of reserved forests, production of nuclear energy and security printing (currency notes) and minting.

ii. Private Sector's Ownership: Government has enacted a law in the parliament enabling the private investors to set up private Export Processing Zones (EPZ). The units in private EPZ will enjoy facilities similar to those in government EPZs. The Private Power Generation Policy has been formulated paving the way for private investment in power generation for which a new Electricity Act and a regulatory commission is on their way. Private investments have already been allowed in gas exploration, gas development, power generation and other mining and exploration activities [13].

iii. Legal security for investment: Foreign Private Investment (Promotion and Protection) Act, 1980 ensures legal protection to foreign investment. Bangladesh is a member of Multi-Lateral Investment Guarantee Agency (MIGA), Overseas Private Investment Corporation (OPIC) of USA and International Centre for Settlement of Industrial Disputes (ICSID). Member of World Intellectual Property Organization (WIPO) and World Association of Investment Promotion Agencies [29].

\section{International road shows and entrepreneurs meet}

Bangladesh Board of Investment (BoI) organized a number of international Road Shows and entrepreneur's meets in Hong Kong, Germany, India, and London, Japan regularly from 2009. In 2015 Road Shows were organized at England, Netherlands, France and Japan [30].

\section{Barriers to Invest in Bangladesh}

1. Long list of permissions/registration/license from different government agencies: To pirate an enterprise in Bangladesh about 37 permissions/registrations required from different government agencies.

2. Absence of good governance and corrupt bureaucracy: A corruption free bureaucracy could offer prompt delivery of government services to enhance investment in Bangladesh.

3. Lengthy Judicial System: Lengthy and cumbersome judicial process is discouraging foreign investors to enter into Bangladesh.

4. Limited capacity to supply adequate electricity and gas to industries: About $47.90 \%$ of people are covering under electrification in Bangladesh. Currently about 7200-7500 MW of electricity is generating in a day. It is not sufficient to provide electricity supply into newer industries as demanded.

5. Absence of efficient physical infrastructure: We have two Sea ports in Bangladesh. But only Chittagong port is active. On 
the other hand only one Dhaka-Chittagong Highway is not sufficient to support total import-export trade of Bangladesh. As a result traffic jam is destroying our valuable time during international trade through this port. We are in need of a Deep Sea Port to enhance our international trade capabilities.

6. Bureaucratic complexity to get registered or permission: Cost of doing business in increasing by the unofficial cost of bureaucracy.

7. Absence of investment promoting agency: We have regulators to provide permissions and operate inspections in industrial establishments but we do not have a government agency to promote investment in larger scale. The SME Foundation is working to promote Small and Medium Enterprises but they do not have mandate to promote foreign investment or large scale local investment.

8. Lack of professionals and sector specific trained man power: We are lagging behind in terms of trained manpower to meet up the demands from a modern industry. It is in terms of operators, trouble shooters or engineers etc. Government has to take the lead to produce sector specific trained manpower to feed the industries as well as create employment of the young generations.

9. Poor imposition of IP (Intellectual Property) law: We have limited understanding and institutional capacity to impose IP relevant laws in Bangladesh. It discourages a high-tech company to enter into Bangladesh.

10. Lack of project specific proposals in hand to attract international investment.

11. Non-cooperation from relevant government agencies like, the Board of Investment, Police, National Board of Revenue, Environment Authority etc.

12. Political unrest and blockades.

13. Absence of standardization/quality infrastructure in home.

14. Absence of technology infrastructure.

15. Differential treatment with the change of government.

16. Lack of administrative coordination among different government bodies.

17. Delay to get services from support organizations.

\section{Recommendations to Improve Investment Climate in Bangladesh}

1. Decreasing number of permissions/registrations/licenses with a predetermined time frame/one stop investment requirement services.

2. Ensuring hassle free and in time delivery of industrial utilities like Electricity, Gas and water etc.

3. Restructuring investment promotion organization i.e. the Board of Investment with new management.

4. Special investment attraction drive with specific project proposals to attract local and foreign investment.

5. Activating entrepreneurship promoters like better business forum or regulatory reform commission.
6. Developing infrastructure as per requirement of tomorrow's business.

7. Developing sector specific demand driven skilled manpower with specific technical knowledge.

8. Establishing investment promotion agency [30]

\section{Concluding Remarks}

Bangladesh is a land of opportunity. We have every potential to grow further. Entrepreneurship development and investment promotion is the most effective tool to make these potentials in reality. New investment brings employment, technology, managerial knowledge to alleviate poverty. Therefore it is the time for the Bangladeshi political leaders to seat together and come to a consensus for the quicker growth of the nation. Increasing institutional capacities for investment promotion and FDI attraction into Bangladesh could lead up toward this dream in near future. We all have a stake to perform for building a prosperous Bangladesh in near future.

\section{References}

1. Lawson S, Heacock D, Stupnytska A (2007) Beyond the BRICS: A Look at the Next 11. Goldman Sachs investment bank.

2. Making Vision 2021 a Reality (2012) Perspective Plan of Bangladesh 2010 2021 General Economics Division, Planning Commission, Government of the People's Republic of Bangladesh 14.

3. The Household Expenditure Survey (2010) Bangladesh Bureau of Statistics, Bangladesh.

4. Labor Force Survey (2010) Bangladesh Bureau of Statistics, Bangladesh.

5. Begum AA, Abdin MJ (2015) Employment Generation and Poverty Alleviation through SME Cluster Development in Bangladesh, Turkish Economic Review 2.

6. Bangladesh Economic Review (2015) Ministry of Finance, Government of Bangladesh 249

7. Bangladesh Economic Review (2015) Ministry of Finance, Government of Bangladesh 307

8. National Industrial Policy (2010) Ministry of Industries, Government of Bangladesh 5

9. FDI (2011) The top 10 nations investing in India.

10. (2011) Investing in Bangladesh A guide for New Investors Embassy of the Kingdom of the Netherlands, Dhaka, Bangladesh.

11. Foreign Direct Investment in Bangladesh 1971-2010 (2010) The Board of Investment, Government of Bangladesh.

12. Muttakin MB, Ahmed $S(2005)$ the Investment Scenario in Bangladesh Problems and Prospects. Pakistan Journal of Social Sciences 3: 534-540.

13. Business Info Bangladesh (2015) Bangladesh - An investment destination in South Asia.

14. Foreign Direct Investment (FDI) in Bangladesh, Survey Report (2014) Statistics Department, Bangladesh Bank.

15. Bangladesh Economic Review (2011) Ministry of Finance, Government of Bangladesh: 317.

16. Gross Domestic Product of Bangladesh at Current Prices, 2009-10 to 2013-14, Bangladesh Bureau of Statistics, Government of Bangladesh.

17. World Investment Report (2014) United Nations Conference on Trade and Development (UNCTAD)

18. http://www.cambodiainvestment.gov.kh/investors-information/fdi-trend.html

19. Bagheri G, Nanehkaran YA (2013) Survey of Foreign Direct Investment in Iran International Journal of Scientific and Technology Research 2: 126-128.

20. Hong BN, Huy D, Thuy NX (2014) FDI Report: Vietnam, International Financial Law Review. 
21. Smith S (2013) Sri Lanka earns $\$ 870 m$ in Foreign Direct Investment in 2013 , the Republic Squire.

22. Foreign Direct Investment (2014) (FDI) in Bangladesh. Survey Report JanuaryJune 2014. Statistics Department, Bangladesh Bank 20.

23. http://www.investmentmap.org/

24. https://en.wikipedia.org/wiki/List_of_countries_by_GDP_(nominal)

25. Alam MS (2012) Foreign Direct Investment in Bangladesh: A Critical Analysis,
South East Asian. Journal of Contemporary Business, Economics and Law 1: 74-80.

26. https://en.santandertrade.com/establish-overseas/thailand/foreign-investment 27. Singapore Department of Statistics (2015) Published at 28 April.

28. https://en.santandertrade.com/establish-overseas/malaysia/foreign-investment 29. http://boi.gov.pk/ForeignInvestmentinPakistan.aspx

30. Nur SA (2015) Bol to sponsor road shows abroad to boost investors' confidence The Financial Express. 